\title{
Consensus
}

Volume 32

Issue 1 Cultural Reception of the Gospel

Article 19

5-1-2007

\section{Between heaven and earth: the religious worlds people make and the scholars who study them}

Sherry Angela Smith

Follow this and additional works at: http://scholars.wlu.ca/consensus

\section{Recommended Citation}

Smith, Sherry Angela (2007) "Between heaven and earth: the religious worlds people make and the scholars who study them," Consensus: Vol. 32 : Iss. 1 , Article 19.

Available at: http://scholars.wlu.ca/consensus/vol32/iss1/19

This Book Reviews is brought to you for free and open access by Scholars Commons @ Laurier. It has been accepted for inclusion in Consensus by an authorized editor of Scholars Commons @ Laurier. For more information, please contact scholarscommons@wlu.ca. 
Between Heaven and Earth: The Religious Worlds People Make and the Scholars Who Study Them

Robert A. Orsi

Princeton: Princeton University Press, 2005

245 pages, $\$ 39.90$ hardcover; 264 pages, $\$ 22.50$ softcover

This book offers an engaging examination of twentieth-century American Catholicism as well as a critique of the methodologies/approaches utilized in religious studies. Orsi begins his book by exploring the complex relationships that form between humans and holy figures and the consequences of these bonds for everyday life. One theme that permeates the book is "religion as relationship," emphasizing both practitioners' relationships between heaven and earth, and the relationship between scholars and practitioners.

In Chapter One, "Mildred, Is it Fun to be a Cripple?," Orsi incorporates the memories of his Uncle Sally's experiences with cerebral palsy and Saint Margaret to explore the heaven and earth relationship, while discussing Catholic notions of pain and suffering. Overall, Orsi suggests that these relationships are ambivalent. He posits that pain or physical distress was central to the American Catholic ethos - it was an opportunity for spiritual growth. However, despite this culture's view, there was also a "deeply resentful and suspicious" perception of sick persons (23). Further, Orsi suggests that ill individuals were able to identify their experiences with a saint's story, which gave their illness meaning.

In Chapter Two, "The Many Names of the Mother of God," Orsi examines the relationship between American Catholics and the Virgin Mary. He suggests that devotional images are media of presence, which are efficacious, serving as points of encounter between humans and sacred figures. For believers, Mary's presence and power are actually present in her images - not merely represented in those images. He states that "Mary was also the clearest sign of Catholic difference in the United States" (64). For example, the possession of a rosary immediately indicated one's Catholic identity. However, he notes that Mary has also been a complicated symbol of unity among American Catholics, especially since various immigrant and migrant groups brought regional and national representations of Mary with them to the ethnic enclaves of American cities. 
In Chapter Three, "Material Children," Orsi postulates that presence is central to the study of lived Catholic experience. He suggests that religious cultures offer multiple media for materializing the sacred, including what he calls a process of "corporalization." This corporalization of the sacred was shaped in the formation of children, i.e., the "realness and presence of the sacred in the bodies and imagination of children" (76).Orsi proposes that American Catholics created a distinctive culture of childhood in the twentiethcentury. He advances that what was being formed was "not children's religious experience but the distinctive quality of modern American Catholicism" (109).

In Chapter Four, "Two Aspects of One Life," Orsi examines whether "meaning-making" is the best way to understand religions. He suggests that when "the transcendent breaks into time," it is much "more confounding and unsettling - socially, culturally, psychologically -than "meaning making"" (111). Reflecting on the stories of his grandmother and Saint Gemma, Orsi perceives that it is precisely the place where the two lives touch in the narrative that he is able to understand his grandmother's devotion and the meaning of the communion of saints. He notes that if meaning is made out of pain and blood, then, the meanings made with religious media can be dreadful and painful. When Orsi thinks about both lives, meaning is not the first word that comes to mind. Instead, he posits that "meaning making begins in wounding, and the process of meaning making is wounding" (145).

In Chapter Five, "Have You Ever Prayed to Saint Jude?," Orsi examines his own experiences of fieldwork. He explores some of the problems facing scholars who work within their own religious culture, including the issue of subjectivity. Picking up on Sartre, Orsi asserts that "research is a relationship" between people (174). Moreover, he suggests that as scholars of religion become preoccupied with themselves as interpreters of meanings, they forget that they also participate in the network of relationships between heaven and earth.

In Chapter Six, "Snakes Alive," Orsi considers some of the problems that form between scholars and practitioners. He proposes that theorizing about religion has emerged according to embedded moral assumptions. He notes that the "mother of all religious dichotomies - us/them - has regularly been constituted as moral distinction - good/bad religion" (183). This, he claims, is the product 
of the development of religious studies in the United States. Further, he asserts that scholars must move beyond "otherizing" (198). He states: "The point is not to make the other world radically and irrevocably other, but to render one's own world other to oneself as prelude to a new understanding of the two worlds in relationship to each other" (202).

Orsi's Between Heaven and Earth is a masterful scholarly achievement that is pleasure to read. It is an interesting mixture of ethnographic fieldwork and Orsi's own family stories. His book provides a useful, informative and insightful examination of popular American Catholicism as well as pertinent issues related to studying one's own religious culture. It will be of interest to both laity and scholars who are interested in North American Catholicism, religious healing, and the academic study of religion.

Sherry Angela Smith

McMaster University

\section{The Gospel of Justification in Christ: Where Does the Church Stand Today? \\ Wayne C. Stumme, editor. \\ Grand Rapids, MI: Eerdmans, 2006 \\ 182 pages. $\$ 26.75$ Softcover}

Those interested in finding an ecumenical dialogue about what the gospel of justification by grace through faith might mean today will find willing conversation partners in Wayne Stumme's edited volume. Although the various perspectives contained therein come from Lutheran, Roman Catholic (including one Canadian), Episcopal, and Reformed theologians, they represent for the most part studied responses to the Joint Declaration on Justification (JD), signed in 1999 by the Lutheran World Federation and the Roman Catholic Church. While other ecumenical documents are also taken up in the book, the impetus is clearly the momentous ecumenical agreement that is the Joint Declaration.

One strong point of this edited volume is its inclusion of dissenting voices. Persons familiar with the difficulties of concluding 